\title{
Renewable Energy Price-Stability Benefits in Utility Green Power Programs
}

Lori A. Bird and Karlynn S. Cory

National Renewable Energy Laboratory

Blair G. Swezey

Applied Materials

Technical Report NREL/TP-670-43532

August 2008 


\section{Renewable Energy Price-Stability Benefits in Utility Green Power Programs}

Technical Report NREL/TP-670-43532

August 2008

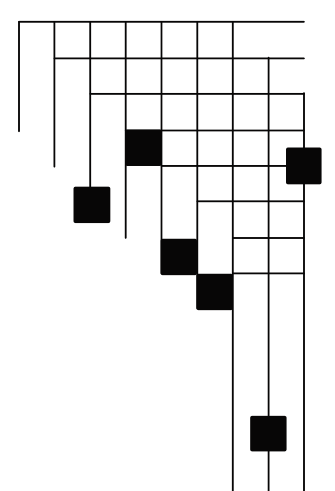

Prepared under Task No. SAO7.8730

National Renewable Energy Laboratory 1617 Cole Boulevard, Golden, Colorado 80401-3393 303-275-3000 • www.nrel.gov 


\section{NOTICE}

This report was prepared as an account of work sponsored by an agency of the United States government. Neither the United States government nor any agency thereof, nor any of their employees, makes any warranty, express or implied, or assumes any legal liability or responsibility for the accuracy, completeness, or usefulness of any information, apparatus, product, or process disclosed, or represents that its use would not infringe privately owned rights. Reference herein to any specific commercial product, process, or service by trade name, trademark, manufacturer, or otherwise does not necessarily constitute or imply its endorsement, recommendation, or favoring by the United States government or any agency thereof. The views and opinions of authors expressed herein do not necessarily state or reflect those of the United States government or any agency thereof.

Available electronically at http://www.osti.gov/bridge

Available for a processing fee to U.S. Department of Energy and its contractors, in paper, from:

U.S. Department of Energy

Office of Scientific and Technical Information

P.O. Box 62

Oak Ridge, TN 37831-0062

phone: 865.576 .8401

fax: 865.576 .5728

email: mailto:reports@adonis.osti.gov

Available for sale to the public, in paper, from:

U.S. Department of Commerce

National Technical Information Service

5285 Port Royal Road

Springfield, VA 22161

phone: 800.553 .6847

fax: 703.605.6900

email: orders@ntis.fedworld.gov

online ordering: http://www.ntis.gov/ordering.htm 


\section{Acknowledgments}

This work was funded by the U.S. Department of Energy's (DOE) Office of Energy Efficiency and Renewable Energy (EERE). The authors wish to thank Linda Silverman, John Atcheson, and the Office of Planning, Budget, and Analysis and the Weatherization and Intergovernmental Program of EERE for their support of this work. The authors also wish to thank the following individuals for their thoughtful review of the document: Carol Harwell of Austin Energy; Jeff Anthony of the American Wind Energy Association; Nicole Wobus of Summit Blue Consulting; and Doug Arent, Barry Friedman, and Gian Porro of NREL. The authors also wish to thank Jennifer Josey and Claire Kreycik of NREL for their editorial support and research support, respectively. Finally, the authors thank the many utility contacts that provided information presented in this report. The authors would also like to recognize Blair Swezey, formerly of NREL and now with Applied Materials in Santa Clara, California, for his contribution to this report. 


\section{List of Acronyms}

$\begin{array}{ll}\text { AMD } & \text { Advanced Micro Devices } \\ \text { EEI } & \text { Edison Electric Institute } \\ \text { EIA } & \text { Energy Information Administration } \\ \text { EWEB } & \text { Eugene Water and Electric Board } \\ \text { FCA } & \text { Fuel cost adjustment } \\ \text { GMP } & \text { Green Mountain Power } \\ \text { IPC } & \text { Interstate Power Company } \\ \text { NREL } & \text { National Renewable Energy Laboratory } \\ \text { O\&M } & \text { Operations and maintenance } \\ \text { OG\&E } & \text { Oklahoma Gas \& Electric } \\ \text { PGE } & \text { Portland General Electric } \\ \text { PSCW } & \text { Public Service Commission of Wisconsin } \\ \text { PURPA } & \text { Public Utility Regulatory Policies Act } \\ \text { REC } & \text { Renewable energy certificate } \\ \text { REI } & \text { Recreational Equipment, Inc. } \\ \text { RPS } & \text { Renewable portfolio standard } \\ \text { WP\&L } & \text { Wisconsin Power \& Light }\end{array}$




\section{Table of Contents}

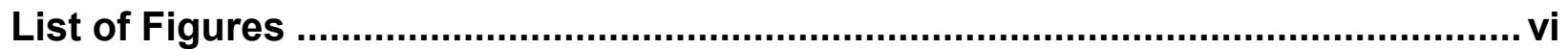

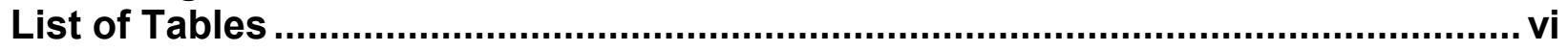

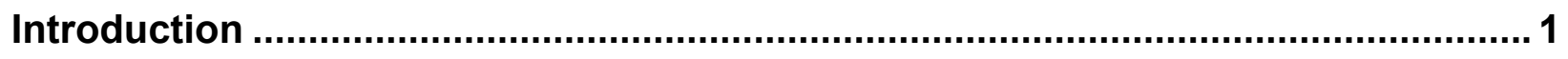

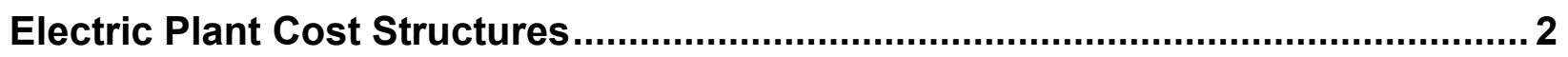

Examining the Value of Fixed-Price Renewables.............................................. 4

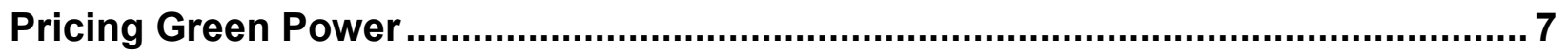

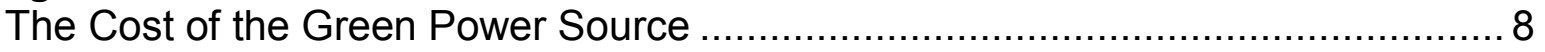

Program Implementation Costs ......................................................... 8

Ancillary Services Costs ......................................................................... 9

Cost of Displaced Generation Resources ………......................................... 10

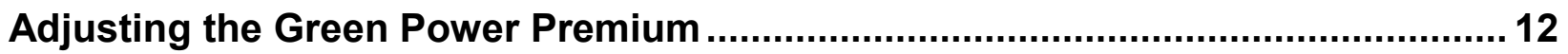

Static Premium Adjustment .................................................................. 12

Dynamic Premium Adjustment ............................................................... 14

Fuel Cost Adjustment Exemption .................................................... 14

Fixed Green Rate .................................................................... 18

Lessons Learned from Experience with Stable-Priced Products ............................ 20

Why Don't More Utilities Offer Fixed-Rate Products? ..................................... 20

Can Fuel Price Stability Be Provided with REC-only Purchases? ....................... 21

Adjusting for Environmental and Other Policy Costs ......................................... 23

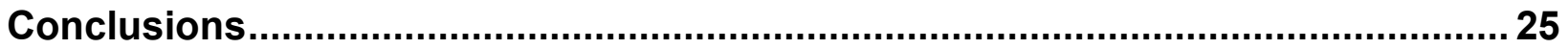

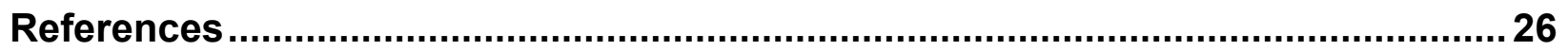




\section{List of Figures}

Figure 1. Comparison of levelized electricity costs for new power plants $(\phi / \mathrm{kWh}$ in $\$ 2006$ ).

Figure 2. U.S. average monthly wellhead natural gas price (January 1990 through November 2007 - nominal dollars per Mcf). 4

Figure 3. Effective price premium of Xcel Energy's Colorado Windsource program ........16

Figure 4. Impact of fuel cost adjustments on base utility rates ................................... 17

Figure 5. Pricing of Austin Energy's GreenChoice product ....................................... 19

\section{List of Tables}

Table 1. Static Green Power Premium Adjustments 13

Table 2. Selected Utilities Exempting Customers from Fossil Fuel Cost Adjustments ... 15 


\section{Introduction}

The guiding principle of voluntary green power markets is that electricity consumers can choose to purchase electricity derived from renewable energy as distinguished from that produced from the standard power system mix, which typically includes electricity generated from fossil fuel and nuclear sources. The willingness of consumers to make these purchases, almost always at higher cost, rests on the value they receive in return, which usually comes in the form of environmental benefits. However, environmental improvement benefits the broader public, not just program participants; all consumers benefit from a cleaner environment regardless of who pays for it. The overall success of the voluntary green power market rests on the willingness of large numbers of individual consumers to pay more for these electricity products, despite the fact that environmental benefits accrue to the public at large.

At the end of 2007, more than 600,000 residential and business customers were participating in utility green power programs, which are offered by about $25 \%$ of utilities nationwide. Customer participation rates in these programs averaged about $2 \%$, with the top programs averaging from $5 \%$ to $20 \%$ (NREL 2008; Bird and Kaiser 2007). Detailed analyses of utility programs have found that the top performers often offer a superior value proposition to consumers (e.g., Wiser et al. 2004). Others advise that the value proposition is of critical importance for garnering the participation of corporate customers (Hanson 2005). There are a number of "private" benefits that utilities often provide to their green power customers, such as individual and public recognition, offering discounts and promotions at local businesses, and providing decals for display in windows of businesses that purchase green power (Bird and Kaiser 2007).

But for the small number of green pricing programs that offer it, an increasingly important value is a fixed-price, rate stability benefit reflecting the fixed costs of the renewable energy sources used to supply the program. Programs offering this benefit protect or exempt their participants from the portion of rate increases that stem from fuel costs. In so doing, these stable-price programs provide a hedge, a kind of insurance policy, against fossil fuel price increases. In a period of dramatic increases and price volatility, particularly in the cost of natural gas, the draw of such a benefit is apparent. This report examines utility experiences when offering the fixedprice benefits of renewable energy in green pricing programs, including the methods utilized and the impact on program participation. It focuses primarily on utility green pricing programs in states that have not undergone electric industry restructuring. ${ }^{1}$

\footnotetext{
${ }^{1}$ In most restructured states, it is more challenging to offer stable-priced products because of the long-term contracting challenges and lack of generation ownership. However, it may be possible to develop stable-priced products through the use of renewable energy certificates (RECs), which is discussed briefly.
} 


\section{Electric Plant Cost Structures}

Green power consists of electricity generated from renewable energy sources such as wind, solar, geothermal, and various forms of biomass. Although hydropower is also considered a renewable energy source, green power products often distinguish between electricity generation from largescale and small-scale (or "low-impact") hydro projects.

A relatively high fraction of the overall cost of a renewable generation project is expended on equipment for resource collection and conversion. With the exception of biomass resources, the renewable "fuel" used in the plant operation is essentially free. ${ }^{2}$ Because these investment costs are incurred upfront, the cost of generation from most renewables-based plants is stable over time, subject only to variations in operations and maintenance (O\&M) costs and resource availability, which tend to be predictable. ${ }^{3}$ Thus, whether a utility owns its renewable generation or purchases renewable energy through a power purchase agreement, the price is known and essentially fixed over time. ${ }^{4}$

Figure 1 illustrates this point, showing a comparison of the levelized generation costs for a coalfired plant with emissions controls (i.e., a scrubber), a natural gas combined-cycle plant, and a wind energy project with and without the federal production tax credit, calculated based on capital, operating, and fuel cost data from the U.S. Energy Information Administration (EIA) (EIA 2008a). Figure 1 shows that there are large differences in the structure of the costs among generating sources. For example, the majority of the projected generation cost for the wind plant is in the upfront capital investment, while most of the natural gas generation cost is in the fuel expense.

The challenge for capital-intensive power projects is that the up-front cost of power projects usually receives greater scrutiny from utility regulators. However, the long-term costs and rate impacts of projects with significant fuel costs are dependent on fuel price projections that cannot be known with certainty. Furthermore, once the project is in operation, fuel price increases and decreases tend to be passed to customers through periodic, real-time fuel price adjustments. The initial capital costs of power plants are more predictable than fuel costs and can be easily planned into electricity rates.

Although nearly 50\% of U.S. electricity supply is generated from coal, the natural gas generation share has been increasing - natural gas generation now accounts for $20 \%$ of U.S. electricity

\footnotetext{
${ }^{2}$ In general, biomass processes are unique among renewables in sharing the combustion process with conventional fossil fuel generation (i.e., biomass facilities procure and burn fuel regularly to produce power over time). For a few biomass generation processes, like anaerobic digestion at a wastewater treatment plant, the fuel may be free.

${ }^{3}$ The uncertainty associated with generation from variable renewable energy technologies (such as wind and solar that are available when the wind and solar resources are available) is typically reflected in ancillary service costs, which is addressed at length later in the paper.

${ }^{4}$ It is important to note that while some contracts with renewable project developers have a simple annual percentage escalator, such escalators are an artifact of typical industry practice rather than an increase in actual costs over time.
} 


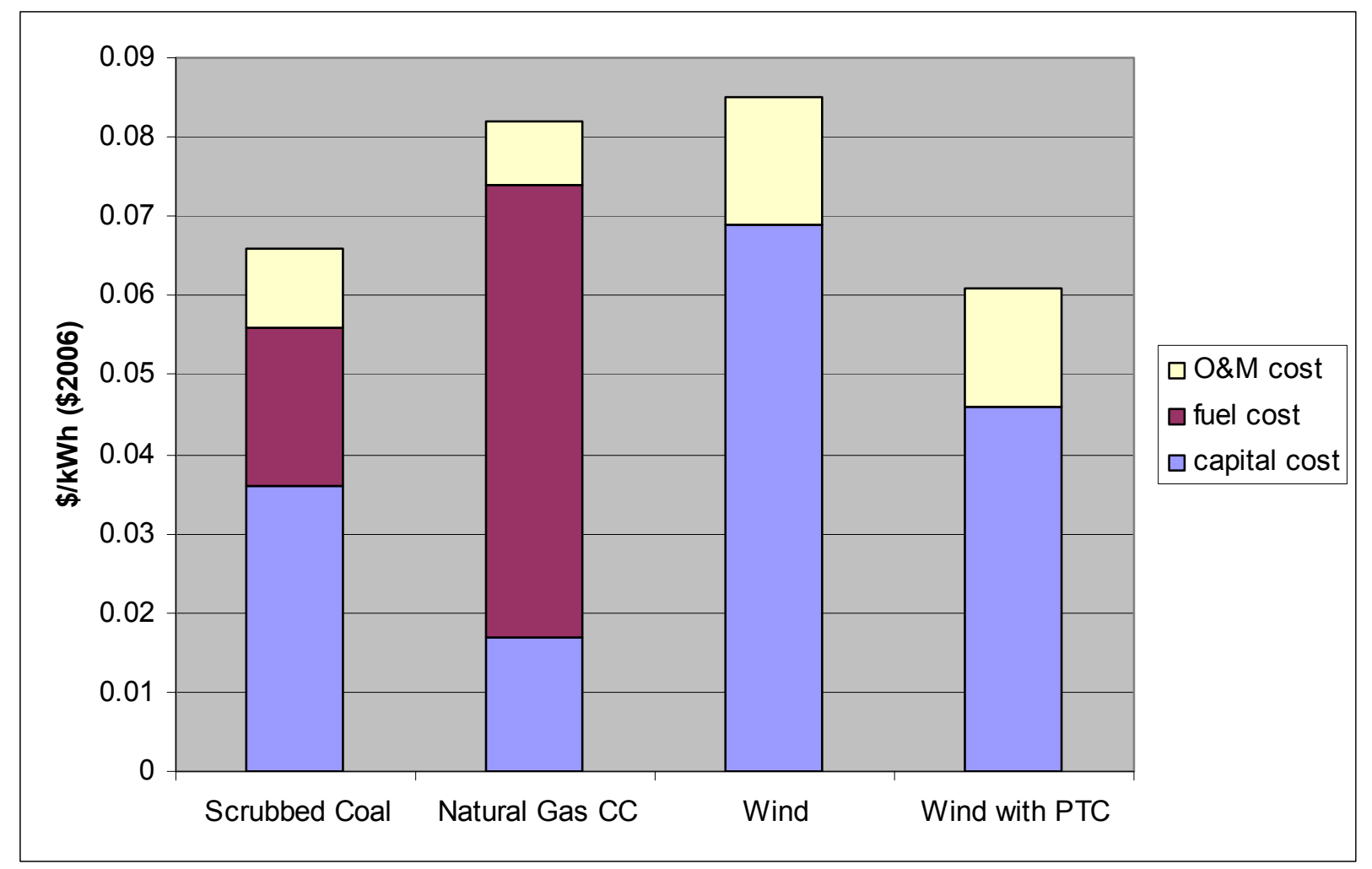

Figure 1. Comparison of levelized electricity costs for new power plants $(\$ 2006)^{*}$

*Note: The natural gas generation cost is based on a natural gas fuel price of $\$ 6.87$ per million Btu in 2006 falling to $\$ 6.93 /$ million Btu in 2030. The coal generation cost is based on a coal fuel price of $\$ 1.69$ per million Btu in 2006 rising to $\$ 1.78$ million Btu in 2030.

Source: Levelized cost calculated based on 2007 cost data from U.S. Energy Information Administration (EIA 2008).

generation compared to $13 \%$ just 10 years ago. The growing dependence on natural gas as a generation fuel has caused electricity prices to increase significantly (EIA 2007).

Recent trends in natural gas prices have highlighted the risks inherent in reliance on fuel-based technologies without fixed-price fuel contracts. Figure 2 illustrates the trend in the average U.S. wellhead price for natural gas since 1990. Not only have higher prices been a burden, but the volatility of prices is also problematic for both operations and planning.

Even coal-fired generation is subject to fuel-price escalation and volatility. EIA data show that the average cost of coal delivered to U.S. electric generating plants rose 30\% from 2004 to 2007 as a result of both minemouth price increases as well as transportation cost increases (EIA 2008b). And spot market coal prices have increased even more dramatically, with Central Appalachian coal prices recently doubling from their low in 2007 (EIA 2008c). Coal generation costs may also be subject to future emissions control costs (i.e., for carbon and mercury) which are generally not reflected in current or projected plant costs.

Typically, these cost increases are passed on to ratepayers. As a result, some electricity customers are beginning to value renewable energy generation for its stable-price characteristics 
in addition to the environmental benefits. And green power customers are beginning to expect to receive this fixed-price benefit as a component of their product purchase. ${ }^{5}$

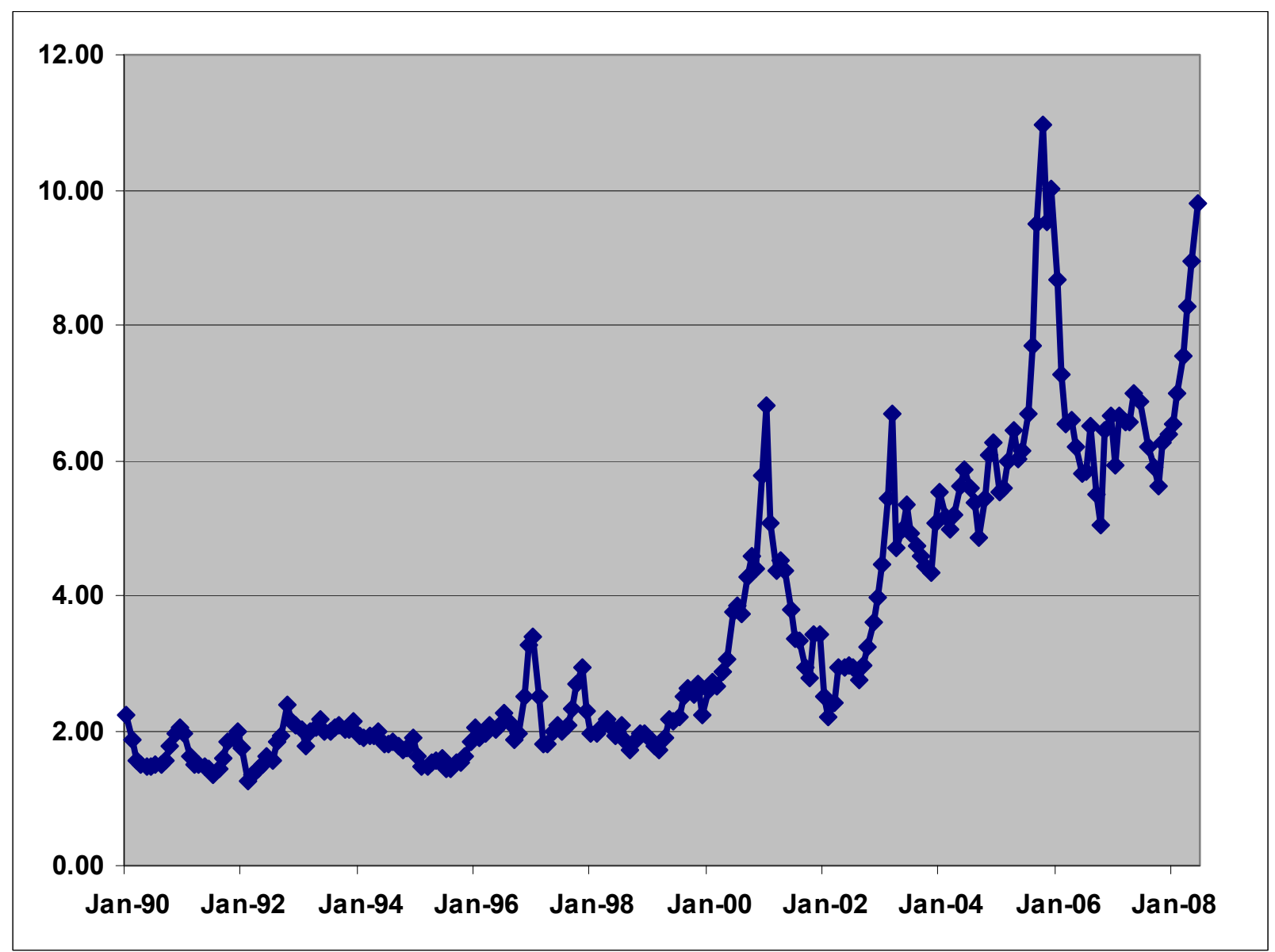

Figure 2. U.S. average monthly wellhead natural gas price (January 1990 through June 2008 Source: U.S. Energy Information Administration nominal dollars per Mcf)

\section{Examining the Value of Fixed-Price Renewables}

What motivates consumers to purchase green power? Utility market research has found that for residential customers, the decision is predominantly an emotional one, while for commercial customers, it is a business decision (Capage 2001). Both sets of consumers are often interested in purchasing green power for its environmental and fuel diversity benefits, and out of an interest in preserving resources and the environment for future generations.

For commercial customers, green power purchases can be motivated by an interest in "doing the right thing," generating customer, shareholder, or employee goodwill, meeting corporate or

\footnotetext{
${ }^{5}$ Green power customers in Long Island voiced frustration over being charged for rate increases due to nonrenewable fuels. For example, see "Lawmaker Says Some Feel 'Ripped Off' by LIPA's Alt-Energy Plan," Newsday, May 25, 2006. Similar articles appeared in the press in Connecticut.
} 
organizational goals for sustainable business practices or operations, or for financial reasons, such as mitigating potential penalties for greenhouse gas emissions in the future or providing a hedge against fuel price volatility (Hagen and Atwood 2006; Holt et al. 2001). Many organizations purchase green power for the carbon emissions benefits because of concerns about global climate change or future carbon regulation. Green power purchases can also be a market differentiator for businesses, and provide co-marketing and co-branding opportunities. And many large purchasers report receiving valuable earned media and other public recognition as a result of their purchases.

The fact that green power commands a premium is a key factor keeping market penetration low. Recent experience shows that when green power prices reach or fall below parity with base rates, a greater number of customers will purchase. For example, in late 2005, Xcel Energy and Oklahoma Gas \& Electric (OG\&E) both quickly and fully subscribed their green power programs when wind energy became cheaper than base rates. ${ }^{6}$ Additionally, Austin Energy, which currently offers a 15-year fixed-rate product, was forced to implement a lottery when the price of its GreenChoice product fell slightly below standard electricity rates. To handle the overwhelming demand, the Austin City Council adopted a resolution calling for the remaining renewable energy supply to be allocated equally among the three customer classes - residential, small commercial, and large commercial — and for the city manager to conduct a drawing to select participants until the program supplies could be expanded (Austin City Council 2006).

Furthermore, research conducted by Portland General Electric shows that even though the key drivers for customers to sign up for the utility's green pricing program are environmental, customers in the segment who were undecided about signing up for the program would be persuaded to enroll if they personally benefited from lower rates in the long run (Hinckley 2005). Therefore, even customers who are primarily motivated by environmental reasons might be more inclined to participate if the program offered price stability or a hedge against fossil fuel cost increases.

With rising fossil fuel and electricity prices, businesses are increasingly looking for price stability in their green power products in order to "hedge" themselves against rising prices (Hanson 2005). Even if renewables might be more expensive initially, the availability of a fixedrate product over a long time period provides much-desired certainty in energy expenditures. This certainty can help businesses better plan their budgets. For example, in March 2006, Recreational Equipment, Inc. (REI), the national cooperative retailer of outdoor gear and apparel, announced a green power purchase of 10 million $\mathrm{kWh}$, with the purchases coming primarily from utilities and other suppliers offering products that would reduce the company's exposure to fossil fuel surcharges (Hagen 2006). ${ }^{7}$

\footnotetext{
${ }^{6}$ Customer sign-ups increased by 13\% from Q3 2005 through Q1 2006; from 30,300 to 34,360 before selling out. The fall in price and consumer interest was documented in a number of news articles, such as "Energy bargain blowing in wind: Xcel's regular electrical customers, facing higher rates, now will pay more than wind-power buyers," The Denver Post, October 12, 2005 "Steady wind means pricier power," The Denver Post, June 14, 2006. ${ }^{7}$ See also REI news release, "REI Steps Up to 20 Percent Green Power," dated March 28, 2006. (http://www.rei.com/aboutrei/releases/greenpower.html)
} 
In addition, Austin Energy has found that its business customers most value the price certainty and savings that come with the utility's fixed-rate product. Advanced Micro Devices (AMD), an Austin Energy green pricing program participant, noted that the fixed-rate product allows the company to reduce overall energy costs. ${ }^{8}$ AMD was one of the first companies in Austin to purchase green power through the Austin Energy Program and has continued to subscribe to subsequent batches of green energy offered since the program was launched in 2000.

While there is a lot of interest in capturing the value of fixed-price renewable power, it may not be straightforward to execute in a green power program. The following sections examine the challenges that utilities face when initially determining a price of a green power product and considering how it could/should change over time.

\footnotetext{
${ }^{8}$ See “AMD Turns Greener," Austin American-Statesman, October 24, 2005.
} 


\section{Pricing Green Power}

This section explores methodologies for pricing green power by considering how utilities typically set their rates and account for the cost differential between renewable energy and conventional energy sources.

In the simplest sense, electricity rates reflect cost recovery of a utility's investments and operating expenses. These costs include: 1) owning generation, 2) owning transmission and distribution assets, 3) a return on owned assets, 4) purchased power contracts, and 5) recovery of various operating expenses, including fuel costs, maintenance, and administration. Generation, transmission and distribution costs are traditionally rolled up or bundled together into a utility's rate $^{9}$ and not tracked separately in traditionally regulated electricity markets. ${ }^{10}$

Because utility costs are bundled together, all generation resources are combined to create a utility "system mix" of generation. In other words, utilities do not normally distinguish between individual generation sources for their customers. Therefore, an equivalent mix of the utility's generation resources and purchased power is provided to each customer.

For green power programs, utilities and regulators are interested in separating the specific costs related to securing green power. In this way, green power products are unique, differentiated electricity products. Since customer participation is voluntary, only those customers that choose to sign up for these programs pay the incremental costs. Green power program participants typically pay the higher cost of renewables in the form of a premium on their monthly bill. There are four main components to the determination of the green power premium: ${ }^{11}$

1. The cost of the green power source. This includes the total cost of electricity and/or environmental attributes from all renewable resources used in the product, whether from wind, solar, geothermal, biomass, or another source, and whether owned by the utility or acquired through a power purchase contract.

2. Program implementation costs. Any additional costs attributed to implementing the green power program, including administration and marketing.

\footnotetext{
${ }^{9}$ It is important to note that there is not a single utility rate that is charged to all customers. The rate is usually distinguished by different customer classes (residential, commercial, and industrial) and generally varies so that large volume purchasers receive a discount.

${ }^{10}$ While this report is focused on utilities in states that have not undergone electric industry restructuring, note that utilities in restructured states changed the way that they tracked generation costs. As electricity restructuring propagated through several U.S. states in the late 1990s and early 2000s, affected utilities were often required to separate out the generation costs in their rates. This disaggregation was done so that if a customer decided to switch to a competitive supplier, the default utility could easily remove their generation costs and replace it with the competitive supplier's costs. As restructuring is active in only 16 states (including the District of Columbia) today, most utilities are not required to separate their generation costs from other costs.

${ }^{11}$ If a utility is using renewable energy certificates (RECs), which represent the environmental attributes of the renewable energy source, to supply the green pricing program, the premium would simply be (1) the cost of the RECs plus (2) program implementation costs.
} 
3. Ancillary services costs. The additional costs incurred to integrate variable output resources, particularly wind, into a utility's system.

4. The cost of displaced utility generation (and capacity) resources. The renewable resource displaces electricity that the utility would otherwise have generated or purchased.

Therefore, the green power premium can be represented as:

$$
\text { Green power premium }=(1)+(2)+(3)-(4)
$$

\section{The Cost of the Green Power Source}

The cost of the green power sources are captured through the specific power purchase agreements for renewable energy or RECs, or through the regulatory approval process for utilityowned renewable projects. As long as these are tracked separately from the rest of the generation mix, the appropriate renewable generation costs can be determined.

One challenge in determining generation costs results from the uncertainty regarding how many customers will enroll in the program and for how long they will participate. In electric markets that have not undergone electric industry restructuring, contracts for generation are typically long-term (i.e., 10 years or more), and investment in owned facilities is generally considered to be for the life of the facility (i.e., 20 years or more). The long-term nature of the resource commitment severely contrasts with the program subscription commitment required of most customers. Most green power programs do not require that customers enroll for a specific term, much less sign up for 10 or 20 years to match the facility or contract life of the renewable power supply source. Therefore, while the annual cost of renewable energy is straightforward to determine, the utility faces some level of risk that will likely be reflected in the product pricing. ${ }^{12}$

\section{Program Implementation Costs}

It is relatively straightforward to determine a green pricing program budget. First, the cost of program administration is directly linked to the staff, equipment, and other resources used to administer the program. Second, the marketing costs can be estimated based on the marketing methods used to publicize the program (e.g., bill inserts, participation in community events). The challenge for determining the level of marketing expenditures lies in determining the appropriate amount of resources needed to attract a sufficient number of customers to the program. Leveraging utility marketing and communications efforts that would be deployed anyway, such as call centers, bill inserts, and utility newsletters, can reduce implementation costs.

The amount of program marketing costs that are attributed to program participants varies among utilities - in some cases green power program marketing costs may be included in the general

\footnotetext{
${ }^{12}$ However, if the utility is also subject to a renewable portfolio standard and is therefore required to procure a certain fraction of renewable energy for its overall load, there may be less risk, because the utility has greater flexibility in managing its overall renewable portfolio between its compliance and voluntary program obligations.
} 
utility marketing budget. Many public utilities in particular take this approach. In some cases, state public benefits funds have been used to cover marketing costs (Hamrin et al. 2006). ${ }^{13}$

\section{Ancillary Services Costs}

Ancillary services guarantee the reliability and security of the electric system by responding to constantly changing electric grid conditions. They are the set of activities and functions that electric system operators and market participants perform in order to: 1) balance electricity supply and demand on a minute-by-minute basis, and 2) prepare for longer-term changes in supply and demand, over time. ${ }^{14}$

Some renewable energy generators, such as those based on wind and solar, have variable output - they cannot be turned on or off to meet the changing demand of consumers. Moreover, their output can fluctuate over a matter of a few minutes or hours. Managing these fluctuations can add costs to the system. These costs largely depend on the level of penetration of the variable-output renewables.

As the largest contributing renewable resource to green power programs, wind power is examined here. According to an International Energy Agency report (Gül and Stenzel 2005) that cites an article by David Milborrow, "For wind penetrations of below around 5\%...deviations in wind output fail to show up in the ebb and flow of daily operation with [such] small grid penetrations." However, there is a cost to incorporating wind at higher penetrations. An examination of five U.S.-based studies with wind penetrations from $10 \%$ to $29 \%$ shows a total operating cost impact ranging from \$2.92/MWh up to \$4.97/MWh (Smith et al. 2007). ${ }^{15}$ The same study claims that "at wind penetrations of up to $20 \%$ of system peak demand, it has been found that system operation cost increases arising from wind variability and uncertainty amounted to about $10 \%$ or less of the wholesale value of the wind energy (Smith et al. 2007)." An international comparison of eleven studies examining balancing and operating costs with wind penetration of $10 \%$ to $25 \%$ of gross demand, show costs that range from $\$ 0.33 / \mathrm{MWh}$ to $\$ 5.20$ /MWh (Holtinnen et al. 2007). Therefore, while the exact costs will be utility-specific, it appears that the grid integration cost for a $20 \%$ wind penetration can be reasonably assumed to be less than $\$ 5.00 / \mathrm{MWh}(0.5 \phi / \mathrm{kWh})$. It is also important to note that wind generation has yet to consistently reach these penetration levels in the United States.

Some utilities have incorporated ancillary services costs in setting green power rates. For example, OG\&E's original $2.0 \notin / \mathrm{kWh}$ wind power premium included a charge of $0.25 \phi / \mathrm{kWh}$ for ancillary services to "firm" the wind energy resource. Austin Energy has also incorporated

\footnotetext{
${ }^{13}$ According to Hamrin et al. (2006): "The use of the general marketing budget is justified to the extent that broader public goals are being supported through public information about renewable energy."

${ }^{14}$ Ancillary services help control the short- and long-term operation of generation supply, transmission equipment, distribution equipment and overall system control. The activities through which ancillary services can be provided include: before-hand scheduling of generation and transmission, real-time dispatch of available generation and transmission (i.e. adjust the schedule for current conditions), generation reserves to instantaneously maintain the supply-demand balance (load-following spinning reserve responds to small changes and operating reserves respond to infrequent, large failures of generation and transmission), real-power loss replacement (adjusting for system losses) and voltage control (generation, transmission).

${ }^{15}$ Note that the study examined eight studies in total; only five of which examined wind capacity penetrations of $10 \%$ or higher.
} 
ancillary services costs in its green rate, starting with the third batch of wind energy used to supply its program.

\section{Cost of Displaced Generation Resources}

The treatment of the cost of the displaced generation resources is the final consideration in determining the green pricing premium. However, defining exactly which generation resources are displaced is not often a straightforward exercise.

While utilities do not typically publicize the methodology for determining the price of their green power products, enough information is available to cite a number of methods. Some utilities have determined the green power rate using the embedded energy costs from all other generation sources. Generally, the term "energy costs" refers to the operating costs of the generation facilities, including fuel costs and any power purchases, and may or may not include the levelized capital costs that repay the utility for past construction of its existing generation facilities. A focus on embedded energy costs means that only existing generation costs are included, without consideration of the cost of new, not-yet-built generation, which may be displaced when a new renewable energy facility is used to supply a green pricing program.

Dakota Electric Association is one example of a utility that used the embedded energy cost approach in pricing its green power options. Its Optional Renewable Energy Rider described the method as follows:

"The monthly renewable energy rate will consist of the weighted average energy cost for all outstanding contracts devoted to this service, minus (the utility's) weighted average wholesale costs of energy from all other sources."16

Another approach is to subtract out the utility's avoided cost which may capture the cost of new generation that may be displaced. An entire discipline developed around the calculation of a utility's "avoided cost," which was a pricing concept first introduced in the Public Utility Regulatory Policies Act of 1978 (PURPA) to encourage greater development of nonutilityowned cogeneration and small power projects. The PURPA statute defined avoided cost as a rate not to exceed "the cost to the electric utility of the electric energy which, but for the purchase from such cogenerator or small power producer, such utility would generate or purchase from another source (U.S. DOE 1986)." Depending on the methodology used, avoided costs may focus on only short run costs or could consider longer run costs as well.

The avoided cost concept has been used in determining green power costs in Minnesota, for example. In the case of Interstate Power Company (IPC):

"IPC calculated its green-pricing premium by summing up the renewable power costs of its three contracts (including the incremental administrative and marketing costs) and subtracting the avoided energy and capacity costs (based on these costs from the most recent rate case). The resulting premium is 1.93 cents per kWh (MN PUC 2002)."

\footnotetext{
${ }^{16}$ This approach is detailed in the following: Dakota Electric Optional Renewable Energy Rider (Schedule 90), issued March 1, 2000. Docket Number: E111/M-00-260 http://www.dakotaelectric.com/ratesched.asp. Since then, the utility has revised its methodology
} 
As a proxy for avoided costs, PacifiCorp considered market prices for electricity in the region in setting the tariff for its Blue Sky green power program in 2002.

"The wind power comes from the Wyoming Wind Energy Project, via a contract with the BPA for 3.0 MW of new wind resources. ... Starting May 1, 2003, the Blue Sky program will include an option to purchase Tradable/Renewable Credits (Green Tags) as well as bundled power to satisfy the requirements of the tariff.

The charge per block is calculated by subtracting the market price of the average of the MidColumbia and Palo Verde annual market indexes from the incremental cost of wind energy at the Company's existing Wyoming wind project (Foote Creek Rim) combined with expected marketing costs and program management costs. Due to reductions in the forecast cost for new wind energy and increases in the forecast for market alternatives, the incremental cost of the new renewable energy is declining. This has translated into a reduced charge per block." ${ }^{\prime 7}$

A final pricing consideration is determining the extent to which the new renewable energy resource offsets the need for additional generating capacity (i.e., whether the renewable energy source should receive any capacity credit). ${ }^{18}$ Different methods have been used across the country to estimate the value that wind capacity adds to a system. Of 13 regions and utilities examined in one study, the capacity value ranges from $10 \%$ to $40 \%$ of the rated capacity of the wind facility (Smith et al. 2007). Utilities should consider the applicability of providing some level of capacity credit for renewable energy supplies. A number of utilities, including IPC in Minnesota, subtract out the capacity costs from their green power tariff, although the extent to which this is done across the industry is largely unknown.

\footnotetext{
${ }^{17}$ This approach is detailed in the following: Washington Utilities and Transportation Commission, "PacifiCorp offers green power under the Blue Sky Program (Schedule 70, New Wind, Geothermal and Solar Power Rider Optional)," http://www.wutc.wa.gov/webdocs.nsf/56866f91116f6154882563da00740317/f1caad7fe4309b7f88256a1d00773053 !OpenDocument, accessed 4/23/08. However, the utility has subsequently revised the method.

${ }_{18}$ The actual capacity value that can be attributed to variable renewable energy to meet customer demand during peak periods is subject to some debate. In order to meet the projected daily peak demand (generally in the afternoon), power system operators need to know how much total system power plant capacity will be available, with a high degree of confidence. And since unexpected events can occur (e.g. substantially higher consumer demand, or an unexpected outage of a power plant), electric systems in the U.S. also require an additional capacity reserve of over $10 \%$ (and often more) of the projected peak load be available. Generally, the cost of maintaining adequate capacity (to meet the peak and the reserve margin) is based on the fixed costs associated with the last power plant that has indicated its capacity is available to the system operator, also called the "marginal" plant. During peak hours of the day, this marginal plant is usually a "peaking facility," whose operation costs are high enough that it only makes economic sense for the plant to operate when electricity prices rise above their fixed costs, plus the cost of fuel. At night, however, customer demand can drop significantly such that low-cost baseload generation can become the marginal facility that must balance its output with customer load. No matter which plant is the marginal facility, the utility pays power plants (including ones it owns) for the availability of capacity throughout the day. For example, in a 2005 rate case filing, Northern States Power (NSP) defines its capacity-related costs as: "all of the fixed costs of peaking plants and also a peaking plant-equivalent portion of base-load costs (Zins 2005)."
} 


\section{Adjusting the Green Power Premium}

There are a number of circumstances which might lead a utility to adjust its green power premium. As described below, several terms in the equation used to determine the green pricing premium may change over time, including the cost of the renewable energy sources, program implementation, ancillary services, or the cost of the utility's nonrenewable generation sources. We characterize the methods of adjusting the premium as either "static" or "dynamic." A static adjustment reflects a one-time premium change while a dynamic adjustment denotes use of a regular premium adjustment mechanism. A utility could employ both static and dynamic mechanisms (i.e., exempting green power customers from fuel cost adjustments and making periodic adjustments to the premium).

\section{Static Premium Adjustment}

Although it is not common practice, a number of utilities have adjusted their green power premiums over time, almost always resulting in a premium reduction. Table 1 provides a summary of utility premium adjustments, including the reasons behind the adjustment which fall into the following general categories:

- The cost of the green power source:

- Renewable energy costs were lower than originally envisioned;

- The program was expanded, incorporating lower-cost renewable energy sources that lowered the overall blended renewable resource cost;

- The utility switched to the use of renewable energy certificates (RECs) at lower cost; and

○ The actual cost of transmission of renewable energy was lower than projected.

- Program implementation costs:

- Lower administrative or marketing costs; and

- Increased customer participation, which enables the utility to spread the fixed costs of program administration over a larger base lowering the $\phi / \mathrm{kWh}$ cost burden.

- The cost of displaced utility generation (and capacity) resources:

○ Increase in the cost of conventional generation sources. 
Table 1. Static Green Power Premium Adjustments

\begin{tabular}{|c|c|c|c|c|}
\hline Utility & $\begin{array}{l}\text { Year of } \\
\text { Change }\end{array}$ & $\begin{array}{l}\text { Initial } \\
\text { Premium } \\
\phi / \text { kWh } \\
\end{array}$ & $\begin{array}{c}\text { Revised } \\
\text { Premium } \\
\phi / \mathrm{kWh} \\
\end{array}$ & Notes \\
\hline Madison Gas and Electric & 2008 & 2.68 & 1.00 & $\begin{array}{l}\text { New wind supply added at lower cost; } \\
\text { wind supply tripled. }\end{array}$ \\
\hline $\begin{array}{l}\text { Tri-State Electric } \\
\text { Cooperative }\end{array}$ & 2008 & 1.25 & 0.4 & $\begin{array}{l}\text { Switch to REC-based purchases. Lower } \\
\text { market prices for RECs. }\end{array}$ \\
\hline $\begin{array}{l}\text { Wisconsin Public Power } \\
\text { Inc. }\end{array}$ & 2008 & 2.0 & 1.0 & $\begin{array}{l}\text { Utility entered into long-term contracts } \\
\text { for renewables. Lowered price as } \\
\text { conventional generation prices have } \\
\text { increased. Also added low-cost landfill } \\
\text { generation to the green power } \\
\text { program's resource mix. }\end{array}$ \\
\hline Alabama Power & 2007 & 6.0 & 4.5 & No reason stated. \\
\hline Puget Sound Energy & 2007 & 2.0 & 1.25 & No reason stated. \\
\hline $\begin{array}{l}\text { Loveland Water and } \\
\text { Power }\end{array}$ & 2006 & 2.50 & 1.50 & Switch to regional RECs product. \\
\hline Madison Gas and Electric & 2006 & 3.33 & 2.68 & $\begin{array}{l}\text { Higher cost of natural gas generation } \\
\text { decreased the price differential for } \\
\text { renewable sources. }\end{array}$ \\
\hline Mason County PUD \#3 & 2006 & 2.00 & 1.00 & $\begin{array}{l}\text { Lower wind energy and transmission } \\
\text { costs. }\end{array}$ \\
\hline $\begin{array}{l}\text { Minnkota Power } \\
\text { Cooperative }\end{array}$ & 2006 & 1.50 & 0.50 & $\begin{array}{l}\text { Higher costs of conventional generation } \\
\text { sources. }\end{array}$ \\
\hline Otter Tail Power & 2006 & 2.60 & 1.60 & $\begin{array}{l}\text { Lower-cost source of wind energy. An } \\
\text { increase in the embedded generation } \\
\text { cost to which the renewable energy } \\
\text { cost is compared; reduced marketing } \\
\text { and promotion costs for the program. }\end{array}$ \\
\hline TECO & 2006 & 5.00 & 2.50 & $\begin{array}{l}\text { Increased use of low-cost biomass in } \\
\text { the program's renewable energy mix. }\end{array}$ \\
\hline We Energies & 2006 & 2.04 & 1.37 & Higher fossil fuel prices. \\
\hline Wisconsin Public Service & 2006 & 1.86 & 1.00 & $\begin{array}{l}\text { Lower renewable energy purchase } \\
\text { costs and administrative costs. }\end{array}$ \\
\hline $\begin{array}{l}\text { Basin Electric Power } \\
\text { Cooperative }\end{array}$ & 2005 & 2.50 & 0.50 & $\begin{array}{l}\text { Greatly expanded wind energy supply } \\
\text { lowered costs; switched to "green tag" } \\
\text { product. }\end{array}$ \\
\hline
\end{tabular}


Table 1. Static Green Power Premium Adjustments (continued)

\begin{tabular}{|c|c|c|c|c|}
\hline Utility & $\begin{array}{l}\text { Year of } \\
\text { Change }\end{array}$ & $\begin{array}{c}\text { Initial } \\
\text { Premium } \\
\phi / k W h\end{array}$ & $\begin{array}{l}\text { Revised } \\
\text { Premium } \\
\phi / k W h \\
\end{array}$ & Notes \\
\hline Lower Valley Energy & 2005 & 1.67 & 1.17 & Eliminated administrative margin. \\
\hline Wisconsin Public Service & 2005 & 2.65 & 1.86 & $\begin{array}{l}\text { Lower renewable energy purchase } \\
\text { costs and administrative costs. }\end{array}$ \\
\hline Avista Utilities & 2004 & 1.80 & 0.33 & $\begin{array}{l}\text { Lower renewable energy purchase } \\
\text { costs. }\end{array}$ \\
\hline Fort Collins Utilities & 2004 & 2.50 & 1.00 & $\begin{array}{l}\text { RECs purchased from new wind energy } \\
\text { project. }\end{array}$ \\
\hline Portland General Electric & 2004 & 3.50 & 1.75 & Lower cost of wind power. \\
\hline TECO & 2004 & 10.00 & 5.00 & $\begin{array}{l}\text { Greater use of lower-cost renewable } \\
\text { resources. }\end{array}$ \\
\hline PacifiCorp & 2003 & 2.95 & 1.95 & $\begin{array}{l}\text { Lower renewable energy costs and } \\
\text { greater customer participation. }\end{array}$ \\
\hline $\begin{array}{l}\text { Basin Electric Power } \\
\text { Cooperative }\end{array}$ & 2002 & 3.00 & 2.50 & $\begin{array}{l}\text { Wind power development costs less } \\
\text { than originally estimated. }\end{array}$ \\
\hline PacifiCorp & 2001 & 4.95 & 2.95 & $\begin{array}{l}\text { Reductions in the forecast cost for new } \\
\text { wind energy and increases in the } \\
\text { forecast for market alternatives. }\end{array}$ \\
\hline
\end{tabular}

\section{Dynamic Premium Adjustment}

Although static premium adjustments help narrow the renewable energy price differential and encourage greater program participation among utility customers, they do not capture the dynamic nature of energy price differentials. Both fuel and electricity prices fluctuate annually, seasonally, daily, and even hourly as they are impacted by electricity demand, changes in the market perception of domestic and global fossil fuel supply and demand, construction of new power plants, electricity transmission congestion, and other factors. The remainder of this section explores two different ways utilities can dynamically adjust the green power premium: 1) by exempting customers from fuel cost adjustments and 2) by substituting a fixed green rate for the energy rate on the customer's bill.

\section{Fuel Cost Adjustment Exemption}

As fuel costs have risen, the use of a fuel cost adjustment (FCA) has become prominent in the utility industry. The Edison Electric Institute (EEI) defines an FCA as "a clause in a rate schedule that provides for an adjustment to the customer's bill if the cost of fuel at the supplier's generating stations varies from a specified unit cost (EEI 2005)." Use of an FCA allows a utility 
to automatically pass through higher (lower) fuel costs - as an adder (credit) to the base raterather than wait for formal rate change approval. ${ }^{19}$ A handful of utilities exempt their green power customers from the FCA under the rationale that green power customers should be protected from costs associated with the utility's fossil fuel or other non-renewable generation sources and for their commitment to support renewable energy sources. ${ }^{20}$

FCA exemption can have a marked impact on the effective or net price differential (net green power premium) as shown in Table 2. Figure 3 shows the net green power premium for Xcel Energy in Colorado over time, compared to the (theoretical) case where the initial green power premium could have remained constant. As shown, the net premium was significantly reduced (and even went negative for a time), as a result of the fuel cost adjustment exemption.

Table 2. Selected Utilities Exempting Customers from Fossil Fuel Cost Adjustments

\begin{tabular}{|c|c|c|c|c|}
\hline Utilities & $\begin{array}{c}\text { Program } \\
\text { Name }\end{array}$ & $\begin{array}{c}\text { Residential } \\
\text { Premium } \\
\text { (c/kWh) }\end{array}$ & $\begin{array}{c}\text { Fuel Cost } \\
\text { Adjustment } \\
\text { (Dec 2007) } \\
\text { (c/kWh) }\end{array}$ & $\begin{array}{c}\text { Net Green } \\
\text { Power } \\
\text { Premium } \\
\text { (Dec 2007) } \\
\text { (c/kWh) }\end{array}$ \\
\hline $\begin{array}{c}\text { Alliant Energy } \\
(\mathrm{WI})\end{array}$ & $\begin{array}{c}\text { Second } \\
\text { Nature }\end{array}$ & 2.00 & 0.50 & 1.50 \\
\hline $\begin{array}{c}\text { Edmond } \\
\text { Electric }\end{array}$ & Pure \& Simple & 0.34 & 0.25 & 0.09 \\
\hline $\begin{array}{c}\text { Madison Gas \& } \\
\text { Electric }\end{array}$ & Wind Power & 2.68 & 0.24 & 2.38 \\
\hline $\begin{array}{c}\text { We Energies } \\
\text { Xcel Energy } \\
\text { (MN) }\end{array}$ & $\begin{array}{c}\text { Energy for } \\
\text { Tomorrow }\end{array}$ & 1.37 & 0.00 & 1.37 \\
\hline
\end{tabular}

\footnotetext{
19 "Automatic adjustment clauses" can be used for other purposes as well. See The Brattle Group, Electric Utility Automatic Adjustment Clauses: Benefits and Design Considerations, prepared for the Edison Electric Institute, November 2006.

http://www.eei.org/industry issues/electricity_policy/state_and_local_policies/adjustment_clauses.pdf

${ }^{20}$ These utilities include: Alliant Energy, Edmond Electric, Holy Cross Energy, Madison Gas \& Electric, OG\&E Energy Services, We Energies, and Xcel Energy.
} 


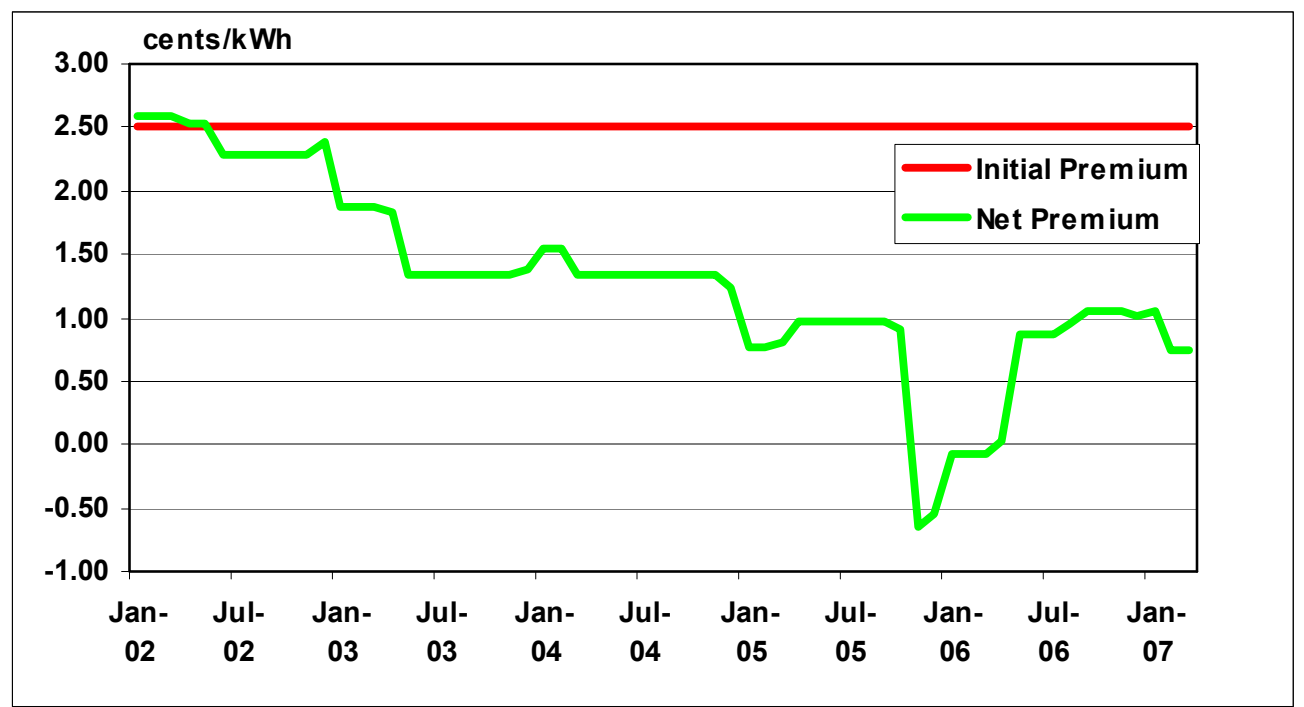

Figure 3. Effective price premium of Xcel Energy's Colorado Windsource program

*Note: The Windsource initial premium was reduced from 2.5cents/kWh in June 2005 and the methodology for calculating the premium was substantially modified in January 2007.

Unfortunately for many green power customers, the FCA represents a short-term collection mechanism used between major rate cases that eventually gets balanced in the next utility rate case. Therefore, in many cases, these higher fuel costs eventually become part of base rates and the FCA is set back to zero, eliminating any pricing benefit. For example, in Wisconsin, Second Nature customers served by Wisconsin Power \& Light (WP\&L) were exempted from FCA surcharges that were instituted after January $1,2001 .^{21}$ Two fuel cost increases totaling $0.58 \phi / \mathrm{kWh}$ lowered the net green power premium to $1.42 \phi / \mathrm{kWh}$ by the middle of 2001 , but a fuel-cost decrease of $0.19 \notin / \mathrm{kWh}$ increased the premium to $1.61 \phi / \mathrm{kWh}$ in March 2002 . In the summer of 2002, the Public Service Commission of Wisconsin (PSCW) approved a rate increase that incorporated the utility's additional fuel costs into the base rate energy charge, eliminating the fuel cost surcharge and reestablishing the Second Nature premium at the full $2 \phi / \mathrm{kWh}$.

Figure 4 depicts this graphically. A typical customer's base rate is adjusted up (or down) depending on the actual cost of fuel for electricity generation. Once the base rate is adjusted, the green power customer pays the new base rate, plus the green power premium, which is higher (or lower) than they should be paying, based on the fixed-price cost of the renewable resources. Therefore, if the green power premium is not adjusted to account for upward changes in the cost of conventional generation, green power customers continue to pay a higher premium rate even as the cost differential between renewables and non-renewables narrows.

Also, focusing only on FCA exemption may ignore energy costs that are already embedded in rates. The amount of fuel cost embedded in base rates can be significant, particularly in recent years. For example, OG\&E increased the amount of fuel costs in its base rates to $2.9 \notin / \mathrm{kWh}$ from $1.5 \phi / \mathrm{kWh}$ as part of the 2005 general rate case.

\footnotetext{
${ }^{21}$ The following discussion refers to the General Service (Gs-1) rate schedule.
} 
From the consumer's perspective, the green power premium would be more fairly priced if it were revisited every time there is a rate case to account for the difference between the cost of the renewable energy resources and the utility's non-renewable generation mix. ${ }^{22}$ With rising energy costs, utilities are rolling higher energy costs into base rates, making this issue more significant for green power consumers. Green power customers obtain the fuel-price stability or hedge benefits of their green power purchases only if changes in energy costs are tracked over time and netted from the green power tariff.

Indeed, some utilities have made adjustments to the base green power premium as a result of adding fuel costs to the base rate, making both dynamic and static adjustments. OG\&E's green power wind rider rate schedule specifically states that the rider needs to "be modified to reflect any changes in the base cost of fuel (OG\&E 2006)." In its 2005 rate case, OG\&E's wind power premium was reduced from $2.0 \mathrm{\phi} / \mathrm{kWh}$ to $0.1 \phi / \mathrm{kWh}$ due to the increase in fuel costs (Corporate 2005). In the case of Xcel Energy in Colorado, during a 2005 rate case, the previous fuel-cost adjustment level was incorporated into the new Windsource price (PSCO 2005). Also, We Energies lowered the base premium for its Energy for Tomorrow program in 2006 from $2.04 \phi / \mathrm{kWh}$ to $1.37 \phi / \mathrm{kWh}$ to reflect higher fossil fuel prices. However, most other programs have not made these kinds of adjustments.

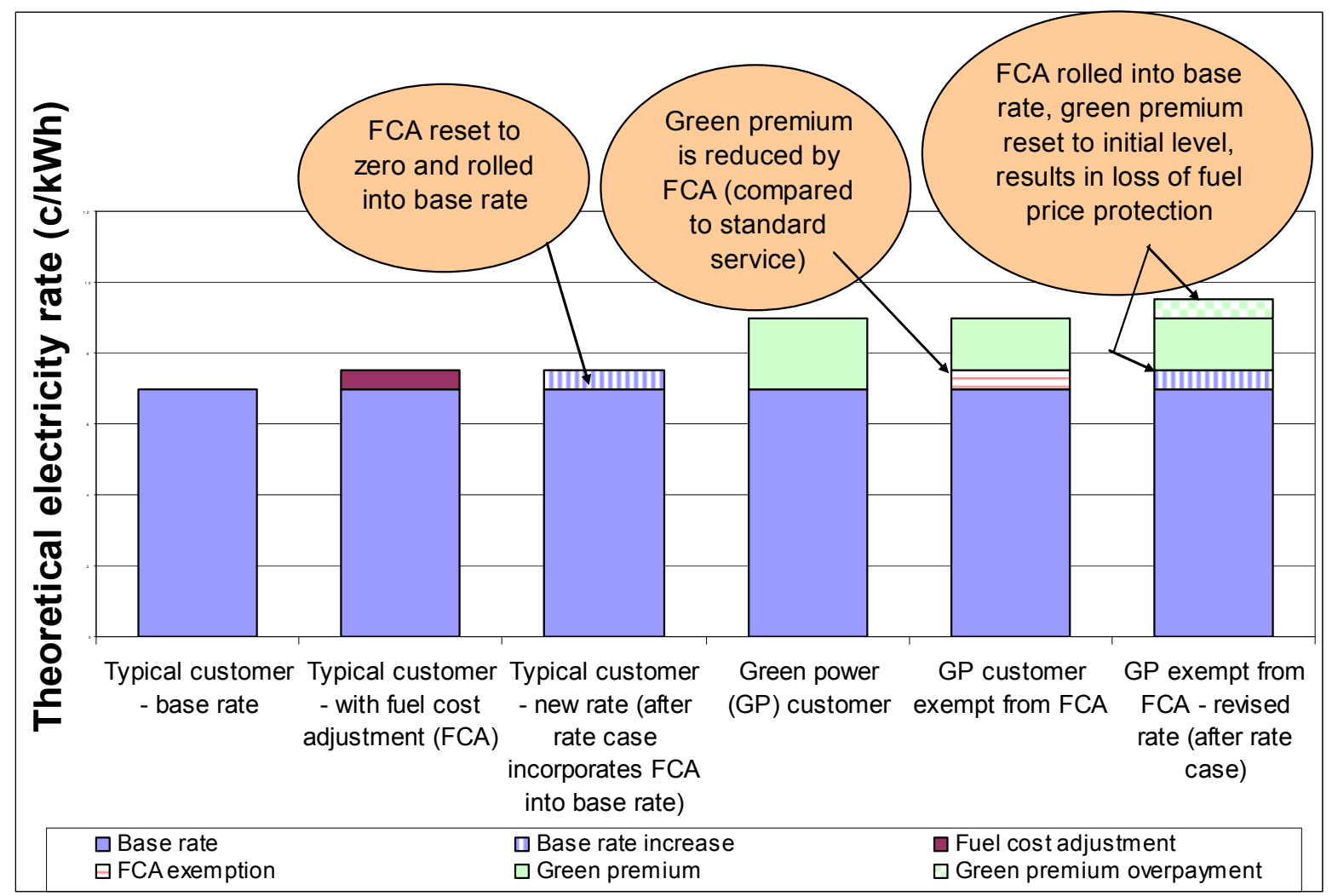

Figure 4. Impact of fuel cost adjustments on base utility rates

\footnotetext{
${ }^{22}$ Of course, the portion of rate increases for distribution, transmission, and administrative costs would need to be appropriately allocated to green pricing program customers.
} 


\section{Fixed Green Rate}

A different approach to protecting green power customers from energy cost changes is to substitute a specific green generation rate for the conventional energy generation rate. ${ }^{23}$ Under this approach, green power customers pay all of the same charges as base rate customers, including transmission, distribution, billing, and administrative expenses. However, instead of paying the standard generation costs, they pay the cost of the renewable energy generation and any supplemental costs (ancillary services and program implementation costs).

Austin Energy has used this approach in pricing its GreenChoice product, which is supplied primarily with wind energy. A key characteristic of the GreenChoice product is the establishment of a separate green charge, which substitutes directly for the utility's fuel charge. The fuel charge is a line item on the customer's bill, consisting of forecasted annual fuel and purchased power costs, and estimated fees and charges from the Electric Reliability Council of Texas (ERCOT) incurred to meet service-area obligations. ${ }^{24}$ The green charge, on the other hand, is determined by the cost of the renewable energy power purchase contracts Austin Energy signs to supply the program, plus additional costs such as ancillary services and product marketing, and is currently fixed for 15 years.

The key factor that allows Austin Energy to offer a fixed -rate green power product is that the renewable energy supply is locked in at a fixed rate for 10 to 20 years, depending on the associated supply contracts. Accordingly, business customers, who are the primary target of the program, must commit to the GreenChoice program for a 15 -year period, ${ }^{25}$ reducing the risk for the utility that demand for the renewable energy project will fluctuate. The utility also has an unbundled rate structure, allowing the green charge to directly substitute for the fuel charge on customer bills.

When GreenChoice was launched in 2000, Austin Energy entered into a contract for $40 \mathrm{MW}$ of wind energy to supply the program. Since then, the utility has expanded the program four times, each time entering into a contract for additional renewable energy generating capacity for the program. With each new contract ("batch") of renewable energy for the program, consumers lock in the price of the latest batch of generation for up to 15 years, depending on the term of the resources procured. Figure 5 compares the green rate to the fuel charge over time and shows the resulting premium paid by customers for each of the five batches of renewable energy. As the figure shows, all green power customers were paying less than those on standard service throughout most of 2006. In January 2008, Austin Energy offered the fifth batch of wind energy at a price of $5.5 \phi / \mathrm{kWh}$ compared to the fuel charge of $3.65 \phi / \mathrm{kWh}$.

\footnotetext{
${ }^{23}$ Utilities that have offered fixed green rates include Austin Energy, Clallum County PUD, and Eugene Water and Electric Board (EWEB). EWEB's Windpower program, which was launched in 1999, was structured so that a "windpower energy charge" was substituted directly for the utility's energy charge. The program was initially offered at a premium of $2.7 \phi / \mathrm{kWh}$ over standard rates, but the effective premium fell over time, and was about $0.91 \notin / \mathrm{kWh}$ for an average customer at the end of 2005. The program became fully subscribed in 2006 and the utility subsequently launched a new program with a different pricing structure. Under the Clallum County PUD program, which was launched in 2003, customers can purchase green power to meet $100 \%$ of their electricity needs at a fixed rate of $6.9 \notin / \mathrm{kWh}$, which initially represented a premium of $0.7 \phi / \mathrm{kWh}$ compared to the utility's standard rate.

${ }^{24}$ Like many other utilities, Austin Energy also includes some portion of its energy costs in base rates and thus its GreenChoice customers are not fully excluded from paying these costs.

${ }^{25}$ Originally, this was a minimum 10 -year commitment.
} 


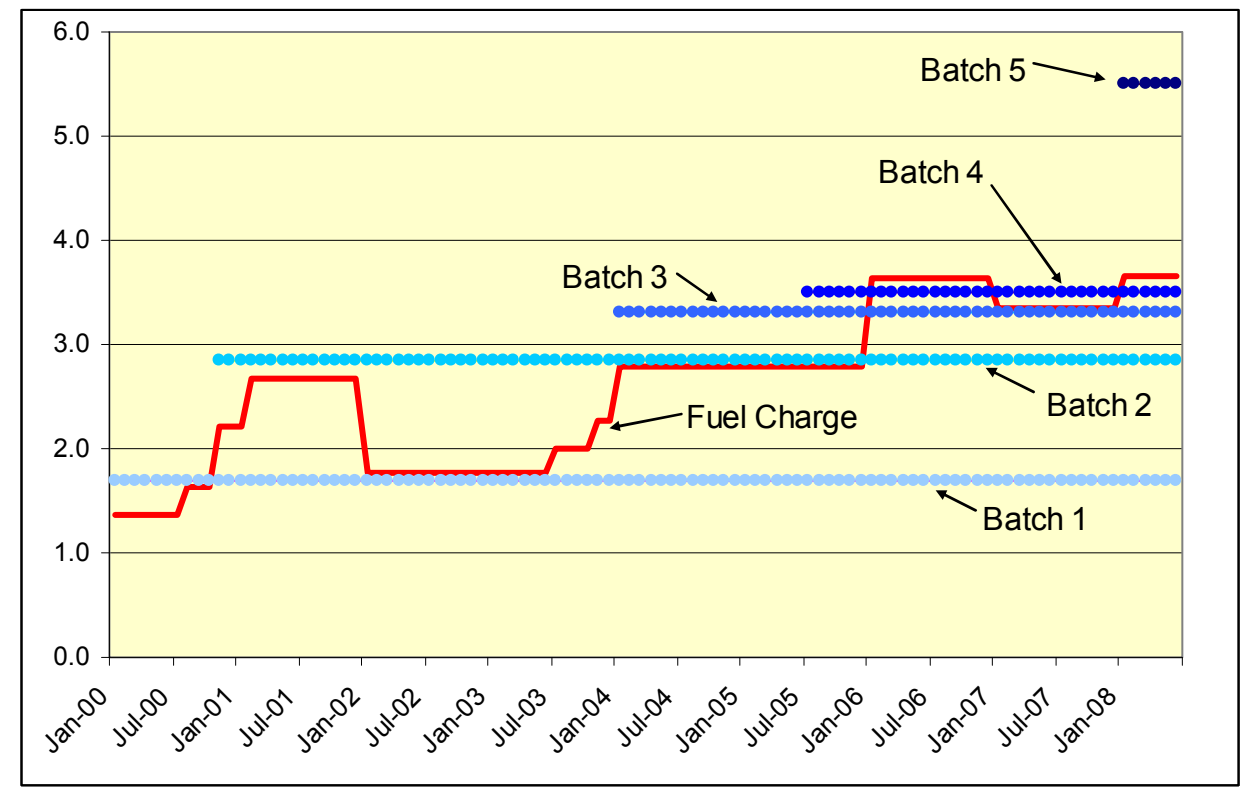

Figure 5. Pricing of Austin Energy's GreenChoice product 


\section{Lessons Learned from Experience with Stable-Priced Products}

Although offering protection from fuel price volatility does not guarantee success in and of itself, it has been a key design element of a number of successful utility green pricing programs. For example, Austin Energy's green pricing program has led the nation in terms of green power sales since 2001 and its program represents about $15 \%$ of all green pricing sales nationally (Bird and Kaiser 2007). In addition, a number of utilities that offer some form of fuel price protection to their green power customers have been ranked in recent years among the top 10 U.S. green pricing programs with respect to green power sales or participation, including Xcel Energy, Edmond Electric, Holy Cross, Oklahoma Gas \& Electric, and We Energies (NREL 2008). Programs that offer protection from price volatility also tend to have lower price premiumsabout half of the utilities offering the lowest premiums for new renewables exempted customers from fossil-fuel charges or offered a fixed green rate, according to the most recent rankings based on 2007 data (NREL 2008).

\section{Why Don't More Utilities Offer Fixed-Rate Products?}

If fixed-rate green power products offer such a compelling value proposition to consumers and contribution to program success, why don't more utilities offer fixed-rate products? A number of reasons are detailed below.

First, the ability to substitute a green rate for either the "energy" rate or fuel charges (as in Austin) requires an unbundled rate structure, that is, the explicit delineation of the various utility cost components on the customer bill. Most utilities in traditionally regulated electricity markets do not bill consumers for electricity in this manner. Generation, transmission, distribution, and administration costs are generally rolled into a standard service charge and a usage charge.

Second is the question of risk allocation. Regulated utilities usually enter into long-term power purchase contracts (10-25 years) or decide to own new renewable generation for the life of the project. As state regulated entities, investor-owned utilities face greater challenges and scrutiny in accepting the risks of long-term renewable energy contracts. If consumers do not make a similar long-term purchase agreement, the utility is exposed to the risk of absorbing the higher cost of the renewable energy generation, either in base rates or with shareholders. While it may be possible to hold nonresidential customers to long term contracts if they perceive a hedge value, it is more challenging to hold residential consumers to similar requirements because of their shorter term planning horizon.

To some degree, publicly owned utilities have greater flexibility in determining green power rates. Publicly owned utilities may also be more willing to accept the position that renewables provide certain public benefits (e.g., fuel diversity, hedge against fossil fuel prices, environmental benefits) that justify absorbing some of the risks of entering into long-term contracts, even if green power demand is uncertain.

Third, the adaptability of a utility's billing system can place some limitations on product design and pricing. According to Mat Northway of Eugene Water and Electric Board (EWEB), "The billing system often dictates the product, i.e., how easy (or difficult) it is to change the billing system (Northway 2001)." The challenges associated with billing system software and 
programming was echoed by Douglas Smith of Green Mountain Power. Substitution of a green rate for the standard energy rate may be difficult to implement in some billing systems (Smith 2008).

Finally, some utilities may have concerns about what happens if the green power product price falls below base rates. The question revolves around whether or not it is problematic for the utility to provide one resource at lower cost to only one segment of the utility's customer base. In fact, one utility (UtiliCorp United) decided to abandon its program altogether and roll the renewable energy supplies into base rates when the cost of renewable energy approached that of its conventional energy sources (Aquila 2001). ${ }^{26}$ On the other hand, if the product is initially offered at above-market rates and customers are willing to make a long-term purchase commitment, then the customers are accepting the risk and locking into a rate that may (or may not) prove to be beneficial over the long term.

Clearly, Austin Energy has been able to successfully address these issues in offering its GreenChoice program. To address the issue of revenue risk, the utility has successfully required its commercial consumers to commit to 10 to 15 -year purchase commitments, which equals the term of its power purchase contracts. The value of the product as a hedge against future fuel price increases has been a compelling motivator for Austin's consumers, particularly its nonresidential consumers, to make long-term purchase commitments. The competitive pricing of the Austin product has also contributed to its success, as consumers perceive the possibility of achieving future cost savings is possible. If the product is priced too high above standard electricity rates initially, consumers may not see it as a compelling hedge against rising fuel prices.

\section{Can Fuel Price Stability Be Provided with REC-only Purchases?}

Of late, a greater number of utilities are supplying their green pricing programs with RECs unbundled from its underlying power. ${ }^{27}$ If RECs are used to supply the program, can the fixedprice benefits of the renewable energy sources be passed on to consumers? That is, if REC costs are additional to fossil fuel-fired generation costs, do the renewables actually convey a fixed price benefit? Or are those benefits retained by the project owner or passed onto the purchaser of the underlying energy from the renewable energy facility? ${ }^{28}$

It is possible to structure a hedge product with RECs, but it is a more complex proposition than if the renewable power were sold bundled with the RECs. To date, a few utilities have structured REC-based hedge products with mixed success.

\footnotetext{
${ }^{26}$ UtiliCorp had been selling a premium-priced wind product to its retail customers since 1999. With the announcement of an additional, larger project, the utility notified its "green pricing" customers that it discontinued the premium product charge and incorporated the renewable energy supplies into its base rates (see http://www.eere.energy.gov/greenpower/markets/pricing. shtml?page=2\&companyid=260).

${ }^{27}$ This is primarily due to increased availability and verification of RECs, as electronic REC tracking systems are now available in regions across the nation and many states now rely on RECs for renewable portfolio standard (RPS) compliance.

${ }^{28}$ The project owner might retain the benefits in the case that the fixed-price renewable electricity is sold as power indexed off of fluctuating electricity prices. Conversely, if the purchaser of the underlying renewable energy agrees to a fluctuating price for power indexed off the electricity market, the project owner could benefit if electricity prices rise and they are able to profit from the difference in their fixed costs and the rising sale price of electricity. Or, if electricity prices decrease, then they developer would get paid less for power produced.
} 
One example was offered by Green Mountain Power (GMP) in Vermont, a REC-based green power product that provided a hedge to customers. Instead of paying the energy charge of the underlying electricity rate (Brown 2006), ${ }^{29}$ customers paid for the five-year fixed price based on the company's projected average cost of generation as well as the five-year market price for NEPOOL Generation Information System-issued RECs (minus purchases from qualifying renewable energy sources) (Brown 2006). This energy price remained fixed for five years and was not adjusted based on rate cases going forward. In addition to the fixed-price energy charge, customers paid for all other applicable charges (e.g., administration, transmission, and distribution). Interestingly, if RECs were not available from the spot market at less than or equal to $5.25 \mathrm{c} / \mathrm{kWh}$, then the available RECs were applied pro rata to participating customers and the green power rate would be reduced. The GMP program had a high premium (initially more than $4 \phi / \mathrm{kWh}$ above the conventional utility rate), because REC prices in New England have been quite high and the program procured RECs on the spot market. The challenge with offering a high rate is that if it does not seem likely that the typical conventional rate will go above the fixed-price of the green power product, there may not be much financial benefit to the consumers participating in the program.

GMP recently revamped the program and moved away from the fixed-price structure because there was consumer confusion over the fixed-price aspect, it was administratively complex (as customers who enrolled in different years had different rates), and some of the utility rates (i.e., the fixed monthly bill option) were not compatible with the earlier program structure, effectively precluding some customers from participating. In addition, GMP decided to concentrate on signing long-term contracts with Vermont-based renewable projects rather than purchasing New England-wide RECs from the spot market (Smith 2008). The new Greener GMP program allows customers to sign up for a REC-based product sourced from Vermont-based RECs with a price premium of $4 \phi / \mathrm{kWh}$ (residential, commercial, or industrial), where the price is subject to change over time. $^{30}$

Portland General Electric (PGE) also had a green power pilot product called Renewable Future, which was offered beginning in January 2007. It provided participating residential and small non-residential customers with a REC-based product that offered a fixed-price hedge against fossil fuel and electricity price volatility. PGE projected their cost of conventional electricity for five years, including a risk premium for potential fossil fuel price volatility, and added the REC price from a specific wind project. Customers signed up for five years and were able to lock in a fixed electricity rate during that timeframe of $9.08 \notin / \mathrm{kWh}$, which represented a premium of about $1.5 \phi / \mathrm{kWh}$ over standard rates. As a pilot program, they had reserved $5 \mathrm{MW}$ of wind RECs and after five months, the program was about $80 \%$ subscribed, showing strong consumer interest. However, due to a change in a portion of the rate unrelated to the cost of the renewables,

\footnotetext{
${ }^{29}$ The energy portion of the underlying rate that is subtracted out equals the average unit cost of: (1) fuel; (2) the energy component of contract purchases; and (3) ISO-NE real-time and day-ahead purchases included in the customer's current rate associated with the customer's currently-effective rate schedule.

${ }^{30}$ For additional information, see the Greener GMP information page and Commercial and Industrial Sign-up pages, Green Mountain Power website, accessed June 11, 2008, http://www.choose2bgreen.biz/greenergmp.php and http://www.choose2bgreen.biz/pdfs/commercial-industrial-signup.pdf
} 
regulators terminated new enrollment in the program five months after its launch. ${ }^{31}$ Still, the pilot demonstrates both the possibility of a REC-based hedge product and consumer interest in the product (Hinckley 2008).

There are a several lessons that can be gleaned from these two REC-based green power products that also provide a hedge benefit. First, developing such a product is complex and properly structuring the rate can be challenging. Second, if the fixed-price of the green power product is set too high, then the customers might question whether they truly get a hedge value, which may limit program participation. Third, if there are portions of the rate that are beyond the utility's control, as was the case for PGE, they should be excluded from the fixed-rate product, where it is feasible to do so. Fourth, while the REC-based product provides less risk to the utility because it can enter into shorter-term contracts for renewable supplies, the REC product hedge structure is less desirable and will not result in a true hedge, if the REC price does not reflect the actual cost of the generation. It is therefore difficult to provide a true hedge if the cost is disconnected.

\section{Adjusting for Environmental and Other Policy Costs}

The treatment of environmental costs is increasingly becoming an issue for green power consumers, as some utilities are recovering the costs of environmental remediation efforts through surcharges or adders on consumer bills. Should green power consumers pay for pollution control costs or other environmental costs associated with conventional fossil fuel plants if they are purchasing renewable energy generation for their electricity needs?

This question was raised when Public Service Company of Colorado (Xcel Energy) implemented a surcharge on customer bills called the "Air Quality Improvement Rider" to recover the costs of voluntarily installing air pollution mitigation equipment on several coal plants in the Denver/Boulder metropolitan area. The PUC decision on the matter called for participants of the utility's Windsource green power program to be exempted from the rider for all of their wind energy purchases (PSCO 1999). On the other hand, the Minnesota PUC approved an "environmental improvement rider" in March 2004 for Northern States Power (NSP) that did not include exemption for Xcel's Minnesota Windsource customers. NSP successfully argued that "although participants in the green pricing program help encourage the diversification of our energy supply, they also benefit from the nonrenewable portions of the utility system and appropriately should share in its costs (Xcel Energy 2002).”

Recently, there has been increased attention focused on the risks associated with $\mathrm{CO}_{2}$ emissions from power generation and interest in mitigating these risks. In response to growing concerns about global climate change, many states and municipalities, as well as several U.S. regions, are adopting policies aimed toward reducing $\mathrm{CO}_{2}$ emissions. Some of these efforts may affect consumer electricity rates or result in surcharges on consumer bills. For example, voters in the city of Boulder, Colorado approved a ballot initiative in 2006 instituting a "climate action plan tax" on electricity consumers in the city to fund the implementation of programs to increase

\footnotetext{
${ }^{31}$ In May 2007, the Bonneville Power Authority cancelled the distribution of a financial benefit from the large federal hydro system to residential customers in the northwest, resulting in a rate increase of $17 \%$. Because this credit was included as a component of Renewable Future rate, but was terminated, the regulators asked the utility to discontinue enrolling new customers on May 31, 2007. Customers currently on Renewable Future are still exempt from the $17 \%$ rate increase and can remain on the rate for the remainder of the five year agreement.
} 
energy efficiency, the use of renewable energy, and reduce motor vehicle emissions. The measure, which took effect in April 2007, did consider the impact on green power customers and specifically exempts them from paying this tax (City of Boulder 2006).

Finally, a number of utilities recover costs for implementing renewable portfolio standard (RPS) policies that require the utility to procure renewable energy to meet a portion of their retail electricity sales. In some cases, these costs are being assessed as a separate adder to utility bills, but for the most part, these costs are rolled into the utility's base rate. Either way, how should these charges be assessed to those green power consumers who are already paying a premium to obtain 100 percent of their electricity from renewable energy sources? If these consumers are assessed the RPS charge and pay a green power adder for all of their electricity needs, they may be charged twice for a portion of their renewable energy purchases. 


\section{Conclusions}

The overall success of the voluntary green power market rests on the willingness of large numbers of individual consumers to pay a premium for these electricity products. Accordingly, electric utilities must present a compelling value proposition for their green power products. The stable-price characteristic of renewable energy generation offers an important and appealing benefit for many consumers. However, the availability of stable-price green power products does not guarantee program success. Other factors are important as well, such as program awareness, the extent and effectiveness of program marketing, and the overall pricing of the product compared to conventional electricity rates.

Several approaches exist to provide green power customers with the stable-price benefits of renewables and provide a hedge against increasing fossil fuel prices. The most straightforward method is to establish a separate green power rate that substitutes for a utility's conventional energy or fuel rate. However, this approach requires both an unbundled rate structure and for the utility to enter into long-term contracts for the renewable energy resources used. The latter condition presents some risk to the utility and its ratepayers if the program is undersubscribed.

An alternative approach is to exempt green power customers from fossil fuel-cost adjustments. However, because FCAs are an interim measure for addressing fuel-cost changes between rate cases, this approach only provides longer-term fuel-price protection if properly structured. In the short-term, FCA exemption provides a stable-price benefit to green power customers, but the benefit is negated if higher fuel prices become embedded in base rates without a comparable downward adjustment of the green power premium.

Finally, utilities can simply revisit the green power price premium when significant fuel price changes occur or when base rates are adjusted, and consider whether the green power premium should also be adjusted as a result. This is the most common approach used by utilities over the years. And there is an open question as to whether green power customers should also be exempted from rate changes resulting from utility expenditures to reduce air emissions from fossil fuel combustion or from state renewable portfolio standard requirements.

The key challenges with all three approaches is in accurately determining the conventional generation costs that are displaced by the increased utilization of the renewable energy resources and designing price structures that are fair to both green power consumers and nonparticipating ratepayers. 


\section{References}

Aquila (March 14, 2001). "UtiliCorp to Purchase Power Generation From Largest Wind Project Constructed in Kansas." News release. Accessed 2008.

http://phx.corporate-ir.net/phoenix.zhtml? $\mathrm{c}=78213 \& \mathrm{p}=$ irol-newsArticle\&ID=158578\&highlight

Austin City Council (January 12, 2006). Resolution 20060112-030: Approve a resolution directing the City Manager to hold a drawing for Austin Energy customers to win an entry into Austin Energy's GreenChoice program.

http://www.ci.austin.tx.us/agenda/2006/downloads/011206030.pdf

Bird, L.; Kaiser, M. (2007). Trends in Utility Green Pricing Programs (2006). NREL/TP-64042287. Golden, CO: National Renewable Energy Laboratory.

Brown, J. (February 9, 2006). Personal communication. Green Mountain Power. Colchester, VT.

Capage, A. (July 2001). "Across the Green Divide: The Macro Lessons." Presented at the $6^{\text {th }}$ Annual Green Power Marketing Conference.

http://www.eere.energy.gov/greenpower/conference/6gpmc01/acapage01.pdf

City of Boulder Ballot Language (September 2006). Accessed April 28, 2008.

http://www.bouldercolorado.gov/files/Elections/2006/certify ballot_2006.pdf

Edison Electric Institute (April 2005). Glossary of Electric Industry Terms. Washington, D.C.: Edison Electric Institute ; p. 3.

http://www.midwestsites.com/stellent2/groups/public/documents/pub/mws_002702.pdf

Energy Information Administration (EIA) (2007). Electric Power Annual with Data for 2006. DOE/EIA-0348. Washington, D.C.: Energy Information Administration, U.S. Department of Energy. October. http://www.eia.doe.gov/cneaf/electricity/epa/epa_sum.html

Energy Information Administration (EIA) (2008a). Annual Energy Outlook 2008 with Projections to 2030. DOE/EIA-0383. Washington, D.C.: Energy Information Administration, U.S. Department of Energy. June. http://www.eia.doe.gov/oiaf/aeo/index.html

Energy Information Administration (EIA) (2008b). "Cost of Fossil-Fuel Receipts at Electric Generating Plants." Monthly Energy Review, July. http://www.eia.doe.gov/emeu/mer/pdf/pages/sec9 15.pdf

Energy Information Administration (EIA) (2008c). Coal News and Market. Accessed June 2008. http://www.eia.doe.gov/cneaf/coal/page/coalnews/coalmar.html

Gül,T.; Stenzel, T. (June 2005). Variability of Wind Power and Other Renewables." Presented at the International Energy Agency conference.

http://www.uwig.org/IEA Report on variability.pdf Original quotation: Milborrow, D. 
(December 2003). "Forecasting for Scheduled Delivery." WindPower Monthly. http://meteo.ist.utl.pt/ jjdd/EDP/WindForecast.pdf

Hagen, K. (April 2006). Conversation with REI Corporate Social Responsibility Program Manager. See also REI (March 28, 2006). "REI Steps Up to 20 Percent Green Power." News release. http://www.rei.com/aboutrei/releases/greenpower.html

Hagen, K.; Atwood. A. (October 2006). "Market Study: Voluntary Green Power Purchasing by C\&I Customers." Presented at the $10^{\text {th }}$ National Green Power Marketing Conference. http://www.eere.energy.gov/greenpower/conference/10gpmc05/hagen.pdf.

Hamrin, J.; Lieberman, D.; Wingate, M. (March 2006). Regulator's Handbook on Renewable Energy Programs and Tariffs. San Francisco, CA: Center for Resource Solutions.

http://resource-

solutions.org/policy/TariffHandbook/Handbook_on_Renewable_Energy_Programs_\&_Tariffs.p df

Hanson, C. (December 2005). “The Business Case for Using Renewable Energy.” World Resources Institute, Corporate Guide to Green Power Markets, Installment 7. http://www.thegreenpowergroup.org/pdf/Installment7.pdf

Hinckley, T. (February 2005). "PGE Flat Rate Wind Power Research.” Presented at the EUCI conference: Marketing Green Power: Profit Opportunities in Selling Renewable Energy.

Hinckley, T. (February 28, 2008). Personal communication. Portland General Electric, Portland, OR.

Holt, E.; Wiser, R.; Fowlie, M.; Mayer, R.; Innis, S. (2001). “Understanding Nonresidential Demand for Green Power." Prepared for the National Wind Coordinating Committee. http://www.nationalwind.org/publications/gpm/non-residential.pdf

Holttinen, H.; Meibom, P.; Ensslin, C.; Hofmann, L. et al. (May 2007). State-of-the-art of Design and Operation of Power Systems with Large Amounts of Wind Power Summary of IEA Wind collaboration. Presented at the European Wind Energy Conference and Exhibition (May 7-10), Milan, Italy. http://www.uwig.org/IEAsystemoperationEWEC2007paper.pdf

Minnesota Public Utilities Commission (MN PUC), (April 11, 2002). Staff Briefing Papers, In the Matter of a Petition by Alliant Energy for Approval of a Renewable Energy Rider, Docket No. E-001/M-01-1954.

Northway, M. (November 2001). "Marketing Green Power - Reaching Your Customer." Presented at the Eugene Water and Electric Board workshop on Seattle, WA.

NREL (April 22, 2008). "NREL Highlights Leading Utility Green Power Programs." News release. Accessed April 28, 2008.

http://www.eere.energy.gov/greenpower/resources/tables/pdfs/0408 topten_pr.pdf 
Oklahoma Gas \& Electric (OG\&E). (May 1, 2006). "Standard Pricing Schedule: GPWR State of Oklahoma." Green Power Wind Rider.

Oklahoma Corporation Commission (OCC) (October 20, 2005). Order No. 516261. In the matter of the application of Oklahoma Gas and Electric Company for an order of the commission authorizing applicant to modify its rates, charges, and tariffs for retail electric service in Oklahoma. http://www.oge.com/content-oge/investors/pdfs/PUD151finalorderOGE.pdf

Public Service Company of Colorado (PSCO). (June 16, 1999). Decision No. R99-678, In the matter of the application of Public Service Company of Colorado for an air quality improvement rider to recover the costs of voluntary emission reductions in three metro area power plants. http://www.dora.state.co.us/PUC/DocketsDecisions/decisions/1999/R99-0678_98A-511E.doc

Public Service Company of Colorado (PSCO). (January 4, 2005). Before The Public Utilities Commission of the State of Colorado Re: The Tariff Sheets Filed By Public Service Company of Colorado, Settlement Agreement, Docket No. 04s-164e, Advice Letter No. 1411 - Electric, Decision, C05-0412.

Smith, D. (June 12, 2008). Personal communication. Green Mountain Power. Colchester, VT.

Smith, J.; Milligan, M.; DeMeo, E.A.; Parsons, B. (August 2007). "Utility Wind Integration and Operating Impact State of the Art." IEEE Transactions on Power Systems, Vol. 22, No. 3; pp. 900-908.

U.S. Department of Energy (U.S. DOE) (March 1986). Emerging Policy Issues in PURPA Implementation. DOE/PE/70404-H1, Washington, D.C.

Wiser, R.; Olsen, S.; Bird, L.; Swezey, B. (February 2004). Utility Green Pricing Programs: A Statistical Analysis of Program Effectiveness. LBNL-54437. Berkeley, CA: Lawrence Berkeley National Laboratory. http://www.eere.energy.gov/greenpower/resources/pdfs/lbnl 54437.pdf

Xcel Energy (2002). "Xcel Energy's Petition for Approval of Rate Rider to Recover Costs of Emissions Reduction Proposal,” Docket No. E002/M-02-633.

Zins, P. (November 2005). "Rate Design and Class Cost of Service Analysis." Testimony presented before the Minnesota Public Utilities Commission. Docket No. E002/GR-05-1428: In the matter of the application of Northern States Power for the authority to increase rates for electric utility service in Minnesota. 


\section{REPORT DOCUMENTATION PAGE}

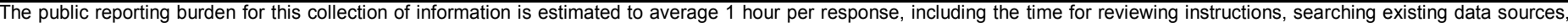

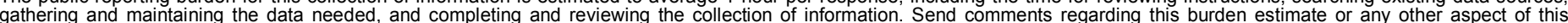

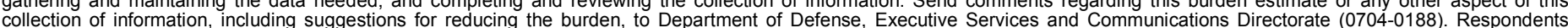

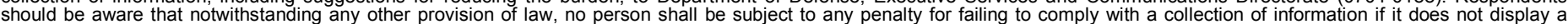

should be aware that notwithstandi

PLEASE DO NOT RETURN YOUR FORM TO THE ABOVE ORGANIZATION.

\begin{tabular}{l|l|l|} 
1. REPORT DATE $(D D-M M-Y Y Y Y)$ & 2. REPORT TYPE & 3. DATES COVERED (FrOm - TO)
\end{tabular}

August 2008

Technical Report

4. TITLE AND SUBTITLE

Renewable Energy Price-Stability Benefits in Utility Green Power

Programs

5a. CONTRACT NUMBER

DE-AC36-99-G010337

5b. GRANT NUMBER

5c. PROGRAM ELEMENT NUMBER

6. AUTHOR(S)

L.A. Bird, K.S. Cory, and B.G. Swezey

5d. PROJECT NUMBER

NREL/TP-670-43532

5e. TASK NUMBER

SA07.8730

5f. WORK UNIT NUMBER
7. PERFORMING ORGANIZATION NAME(S) AND ADDRESS(ES)

National Renewable Energy Laboratory

1617 Cole Blvd.

Golden, CO 80401-3393
8. PERFORMING ORGANIZATION REPORT NUMBER

NREL/TP-670-43532

9. SPONSORING/MONITORING AGENCY NAME(S) AND ADDRESS(ES)

10. SPONSOR/MONITOR'S ACRONYM(S) NREL

11. SPONSORING/MONITORING AGENCY REPORT NUMBER

12. DISTRIBUTION AVAILABILITY STATEMENT

National Technical Information Service

U.S. Department of Commerce

5285 Port Royal Road

Springfield, VA 22161

13. SUPPLEMENTARY NOTES

14. ABSTRACT (Maximum 200 Words)

This paper examines utility experiences when offering the fixed-price benefits of renewable energy in green pricing programs, including the methods utilized and the impact on program participation. It focuses primarily on utility green pricing programs in states that have not undergone electric industry restructuring.

15. SUBJECT TERMS

NREL; Energy Price-Stability Benefits; Utility Green Power Programs; Blair Swezey; Karlynn Cory; Lori Bird

\begin{tabular}{l} 
16. SECURITY CLASSIFICATION OF: \\
\begin{tabular}{|l|l|l|}
\hline $\begin{array}{c}\text { a. REPORT } \\
\text { Unclassified }\end{array}$ & $\begin{array}{c}\text { b. ABSTRACT } \\
\text { Unclassified }\end{array}$ & $\begin{array}{l}\text { C. THIS PAGE } \\
\text { Unclassified }\end{array}$ \\
\end{tabular} \\
\hline
\end{tabular}

\begin{tabular}{l|l} 
17. LIMITATION & 18. NUMBER \\
OF ABSTRACT & OF PAGES \\
UL & \\
& \\
\hline
\end{tabular}

19a. NAME OF RESPONSIBLE PERSON

19b. TELEPHONE NUMBER (Include area code) 